\title{
All Things are Live, A New Theory. When does it Respond? It Depends. Make the Brain More Elasticity, try to Go against the Rules, will See More
}

\author{
Hamouda $\mathrm{AF}^{1-3 *}$ \\ ${ }^{1}$ Department of biochemistry, Faculty of Science, University of Alexandria, Alexandria, Egypt \\ ${ }^{2}$ Medical Laboratory Technology Department, Faculty of Applied Health Sciences, Jazan \\ University, Jazan, Kingdom of Saudi Arabia \\ ${ }^{3}$ Poison Control and Medical Forensic Chemistry Center, Ministry of Health, Jazan, Kingdom of \\ Saudi Arabia
}

*Corresponding author: Asmaa Fathi Hamouda, University of Alexandria, Alexandria, Egypt, Tel: +966500257869; Email: asmaakingdom1@yahoo.com

\section{Opinion}

All creature is living they transform from status to status. Each status or situation is part of the creature curve. All things are living and have a life curve. Science is classified things according to living and non-living things that according to the presence of seven criteria of life that include organization, metabolism, homeostasis, growth, reproduction, response, and evolution. Living things such as humans, dogs, and trees are our criteria of life. Nonliving things may have some features of life, but not all. For example, crystals of snow are organized, but they do not own cells. Snow can grow but do not include the other criteria of life. Fire can grow, reproduce by initiating new fires, and react to stimuli, and even be said to "metabolize." However, fire is not organized, does not control homeostasis, and lacks the genetic knowledge needed for evolution. Living things have some features of life when they become nonliving, but miss others. For example, if one studied at the wood in a chair under a microscope, it might observe traces of the cells that practiced to make up the living tree [1].

Nevertheless, the wood is no longer alive, and, having been built into a chair, can no longer grow, metabolize, have homeostasis, respond, or reproduce. The question of what it expects to be alive continues unsolved. For example, viruses are small protein and nucleic acid compositions that can only replicate inside host cells. Viruses have several of the characteristics of life. However, viruses do not have a cellular structure, nor can they reproduce without a hostess. So, it is not clear that viruses possess homeostasis, and they do not transfer out their metabolism [2]. The point is a science still not be sure or did not discover other presence of a feature so that we will see in this new theory.

Of miracles and verses given to Mohamed messenger of God by the Prophet (peace and blessings of Allah be upon him) in support of his call: 1-Trunk is crying when it replaced by the new pulpit in a mosque, and Mohamed wiped his hand on him. 2-the Prophet stood on a mountain (AHAD) shaken, and he spoke to the mountain; the mountain is listened and respond. Also, the fire when God said 0 fire, being cold and peace to Abraham. Also, talking wood when Adam descended from heaven to earth, according to the news that might reach the point of myth, he descended by the "stick of Moses" from heaven, and stayed in the land until the angel Gabriel handed over to the prophet Moses. Moses was said to lean on it; Which uses them to walk and stand, and hit the branches of the trees, fall fruit, and easy on his sheep to eat. It was said that if she attacked seven or an enemy, she would fight him and fight him away from them and the Prophet of God Moses. If some sheep moved away from the herd, that stick would ensure that they were returned. To him again, as it was said that the length of ten arms $[3,4]$. There is no created being that does not celebrate the praises of Allah. But human did understand not their glorification because it is not like their languages. So please respect and appreciate everything in the universe, everything is living. 
Physical Science \& Biophysics Journal

\section{References}

1. Bjorn P, John (2009) Living Thing. Metacritic, CNET Networks.

2. Research summaries Tenth World Conference Scientific miracles in the Quran and Sunnah.

3. The Glorious Quran.

4. $10^{\text {th }}$ international conference in scientific miracles researches in the Qur'an and Sunnah, Turkey. 